\section{Broadening Participation in Undergraduate Research Experiences (UREs): The Expanding Role of the Community College}

\section{James A. Hewlett*}

Finger Lakes Community College, Canandaigua, NY 14424
$S^{c}$ everal years ago, I was invited to speak at a conference focused on active-learning methods for science instruction. After introducing me by name and title, the conference moderator proceeded to inform the audience that what they would soon learn was that these teaching methods were being used "EVEN at community colleges." Following an awkward pause, I was able to approach the podium and fulfill the promise of the moderator-community college faculty are capable of innovating in the classroom.

Any national effort to increase the number and diversity of science, technology, engineering, and mathematics (STEM) graduates must include our nation's community colleges. The American Association of Community Colleges (AACC) reported that in the Fall of 2015 (most recent data), 12.2 million undergraduates were enrolled at a community college - a number that accounted for $41 \%$ of all U.S. undergraduates (AACC, 2018). Moreover, our community colleges educate $36 \%$ of first-generation students, $43 \%$ of African-American students, 53\% of Hispanic students, and 56\% of Native American students. These statistics highlight the central role community colleges must play in efforts to increase access, equity, and diversity within STEM education.

As executive director of the Community College Undergraduate Research Initiative (CCURI), I have been at the center of efforts to understand how to scale effective practices such as undergraduate research experiences (UREs). UREs have been shown to positively impact persistence and completion in STEM programs (Nagada et al., 1998; Barlow and Villarejo, 2004; Gilmer, 2007; Carter et al., 2009; Jones et al., 2010; Espinosa, 2011; Graham et al., 2013), time to degree completion (Kinkel and Henke, 2006), academic achievement (Kinkel and Henke, 2006; Gilmer, 2007; Jones et al., 2010; Junge et al., 2010), and interest in postgraduate STEM educational opportunities (Lopatto, 2007; Carter et al., 2009; Junge et al., 2010). The traditional apprenticeship-style URE, with its low student to faculty ratio, is not feasible in light of recommendations to involve all students in research as early in their educations as possible (President's Council of Advisors on Science and Technology, 2012). Community colleges provide a test bed for how to ensure this practice reaches a large and diverse set of learners.

The problem facing the community colleges is not the reliance on an apprentice structure for their URE programs, but the lack of an undergraduate research culture altogether (Hewlett, 2016). This issue is reflected in how data on the community college student experience are collected. For example, the Community College Survey of Student Engagement (CCSSE) is the 2-year institution version of the National Survey of Student Engagement (NSSE). The surveys pose very similar questions, with one notable exception. The NSSE asks whether students have engaged in a research project with a faculty member; the resulting data show $~ 19 \%$ of 4-year college students will have engaged in this type of activity before graduation. The percentage at community colleges is unknown, because the corresponding section on the CCSSE surveys the
Kenneth Gibbs, Monitoring Editor Submitted Nov 15, 2017; Revised May 29, 2018; Accepted Jun 5, 2018

CBE Life Sci Educ September 1, 2018 17:es9

DOI:10.1187/cbe.17-11-0238

*Address correspondence to: James A. Hewlett (hewletja@flcc.edu)

(c) 2018 J. A. Hewlett. CBE-Life Sciences Education (C) 2018 The American Society for Cell Biology. This article is distributed by The American Society for Cell Biology under license from the author(s). It is available to the public under an Attribution-Noncommercial-Share Alike 3.0 Unported Creative Commons License (http://creativecommons.org/licenses/ by-nc-sa/3.0)

"ASCB®" and "The American Society for Cell Biology ${ }^{\circledR}$ " are registered trademarks of The American Society for Cell Biology. 
TABLE 1. Known barriers to integrating research into the student experience at community colleges

\begin{tabular}{|c|c|}
\hline Barrier & CCURI recommendation \\
\hline Limited financial resources & Make use of low-cost or externally supported research projects (e.g., SEA-Phages). \\
\hline $\begin{array}{l}\text { Incompatible faculty model } \\
\text { (e.g., high teaching loads) }\end{array}$ & $\begin{array}{l}\text { Integrate research with teaching through a course-based undergraduate research experience (CURE). CUREs not } \\
\text { only address teaching loads, they accommodate a diverse student population, many of whom work outside } \\
\text { of class and are limited by credit limits and financial aid restrictions. Approximately } 88 \% \text { of CCURI partners } \\
\text { implement CUREs. }\end{array}$ \\
\hline Limited student preparation & $\begin{array}{l}\text { Employ first-year pedagogical interventions (e.g., active learning) as a way to scaffold the experience and } \\
\text { prepare students for the research endeavor. This helps to address the significant barriers many community } \\
\text { college freshmen face with respect to their success in a STEM program (Lloyd and Eckhardt, 2010)—a } \\
\text { significant number require developmental course work or supplemental instruction (Zeidenberg et al., } \\
\text { 2007). }\end{array}$ \\
\hline Limited faculty preparation & $\begin{array}{l}\text { Use a diverse suite of faculty development opportunities designed to train partners in implementing various } \\
\text { technology platforms, standard discipline-specific research techniques, and active-learning strategies (CCURI } \\
\text { has developed many such opportunities). Many community college faculty have limited experience in } \\
\text { current research techniques (Provasnik and Planty, 2008); thus, efforts to increase research capacity at a } \\
\text { community college should include resources for ongoing faculty development and training. }\end{array}$ \\
\hline Isolation from networks & $\begin{array}{l}\text { Make use of the variety of meta-analytical studies developed by CCURI to capture innovative and effective } \\
\text { practice resources when constructing new programs (CCURI, 2018). Sustainable undergraduate research } \\
\text { programs then become an entry point for institutions to engage in research networks through disciplinary } \\
\text { societies and the Council on Undergraduate Research (2018). }\end{array}$ \\
\hline $\begin{array}{l}\text { Marginalization from the } \\
\text { science research endeavor }\end{array}$ & $\begin{array}{l}\text { Cultivate collaborative relationships with 4-year institutions located within the community college's service area } \\
\text { (Hirst et al., 2014) and engage in scientific disciplinary societies and organizations as a way to showcase } \\
\text { research efforts and foster novel collaborations. }\end{array}$ \\
\hline Limited administrative support & $\begin{array}{l}\text { Align the shift to integrate research with institutional priorities that are apparent in the college's vision and } \\
\text { mission statements, strategic plans, hiring practices, and program assessments. Include both faculty and } \\
\text { administrators in teamwork to expand familiarity with current research and recommendations on STEM } \\
\text { education and education reform. }\end{array}$ \\
\hline
\end{tabular}

level of participation in remedial course work. Two-year college students are simply not asked about undergraduate research. This difference reflects not only the general assumption that mentored research does not occur at community colleges but also that bias against community colleges is built into the entire system.

However, I know from experience that UREs can be effectively implemented in the community college context to benefit a diverse group of learners. In 2001, my colleagues at Finger Lakes Community College and I conducted a self-study using root cause analysis (Rooney and Heuvel, 2004) to better understand the barriers to developing UREs and potential strategies suited to our context. The study uncovered several interesting and unanticipated issues that were unrelated to the oft-cited financial barriers or ill-prepared students. For example, weak connections to external networks of community colleges and science researchers were found to be a serious barrier to our efforts. The results were compiled and used to create a set of principles for integrating research experiences into a community college. After an initial rollout at FLCC, these principles were tested at six partner institutions with support from the National Science Foundation. The result was the establishment of CCURI.

CCURI is currently a national network of 115 community colleges in 39 states and two countries focused on the development and implementation of undergraduate research programs (www.ccuri.org). The CCURI model, which was originally constructed to address barriers at FLCC, has been modified and expanded for implementation throughout the CCURI network. In its current form, the CCURI model incorporates solutions to the known barriers to integrating research into the student experience at community colleges (Table 1).

These recommendations are predicated on knowing your institutional culture. Each community college, like each 4-year institution, has particular strengths and particular goals in seeking to move to a culture in which research is an integral part of the student experience. Some community colleges join CCURI with a focus on overall completion rates, while others are looking to increase their population of STEM students by recruiting more students from underrepresented groups. Whatever the reason, implementation must be focused on the target goal, and implementation strategies must take into account institutional strengths and peculiarities. CCURI delivers a 3-day workshop for institutions to send teams of professionals to help construct strategic plans for their programs. Once an institution establishes and understands the specific goals for its program, the resources required to implement the plan can be identified and developed around the anticipated barriers aligned with those goals. Strategic thinking and planning are the hallmarks of success for the continued growth of the community college undergraduate research community.

We believe that enabling our nation's community colleges to become full participants in the active practice of research requires having a better understanding of how to drive institutional-level change that can lead to a significant paradigm shift with respect to how we view the role of the community colleges in STEM educational reform efforts. The growth of community college participation in the undergraduate research community continues in spite of the many barriers that these institutions 
face, including public misperceptions, stigmas associated with working at and attending a community college, and unfavorable portrayals in mass media. These challenges often make it difficult for this institution type to be perceived as an equal in developing innovative solutions to address the pressing challenges that face our nation's higher education system (Capriccioso, 2006; Handel, 2008; Hewlett, 2009; Labov, 2012; National Academy of Engineering and National Research Council, 2012). The percentage of students participating in a URE at community colleges is undoubtedly lower than what would be found at 4-year institutions, but any national reform effort to increase access and equity with respect to participation in high-impact STEM activities like undergraduate research must include community colleges if it is to be successful at scale. The time has come for these institutions to not only be recognized for their expanding role, but for other organizations and institution types to reach out and engage community colleges as full partners and collaborators in the research community.

\section{ACKNOWLEDGMENTS}

This material is based upon work supported by the National Science Foundation under Grant No. 1524353.

\section{REFERENCES}

American Association of Community Colleges. (2018). Fast Facts. Retrieved May 18, 2018, from www.aacc.nche.edu/research-trends/fast-facts/

Barlow, A. E. L., \& Villarejo, M. (2004). Making a difference for minorities: Evaluation of an educational enrichment program. Journal of Research in Science Teaching, 41(9), 861-881.

Capriccioso, R. (2006, May 5). Facing Down the "Snob Factor." Inside Higher $E d, 1$. Retrieved May 17, 2018, from www.insidehighered.com

Carter, F. D., Mandell, M., \& Maton, K. I. (2009). The influence of on-campus, academic year undergraduate research on STEM Ph.D. outcomes: Evidence from the Meyerhoff Scholarship Program. Educational Evaluation and Policy Analysis, 31(4), 441-462.

Community College Undergraduate Research Initiative. (2018). Publications Retrieved May 19, 2018, from www.ccuri.org/publications

Council on Undergraduate Research. (2018). Programs for Community Colleges. Retrieved May 23, 2018, from www.cur.org/projects_and _services/special_projects/community_colleges

Espinosa, L. L. (2011). Pipelines and pathways: Women of color in undergraduate STEM majors and the college experiences that contribute to persistence. Harvard Educational Review, 81(2), 209-241.

Gilmer, T. C. (2007). An understanding of the improved grades, retention and graduation rates of STEM majors at the Academic Investment in Math and Science (AIMS) program of Bowling Green State University (BGSU). Journal of STEM Education, 8(1-2), 11-21.

Graham, M. J., Frederick, J., Byars-Winston, A., Hunter, A. B., \& Handelsman, J. (2013). Increasing persistence of college students in STEM. Science, 341(6153), 1455-1456.
Handel, S. J. (2008). Close, easy, and cheap: Perceptions and misperceptions of America's community colleges (Working Paper 1). New York: College Board.

Hewlett, J. (2009). The search for synergy: Undergraduate research at the community college. In Cejda, B. D. (Ed.), Undergraduate research at community colleges (pp. 9-18). Washington, DC: Council on Undergraduate Research.

Hewlett, J. A. (2016). Undergraduate research at the community college: Barriers and opportunities. In Murray, D. H., Obare, S. O., \& Hageman J. H. (Eds.), The power and promise of early research (pp. 137-151) Washington, DC: American Chemical Society.

Hirst, R. A., Bolduc, G., Liotta, L., \& Packard, B. W. L. (2014). Cultivating the STEM transfer pathway and capacity for research: A partnership between a community college and a 4-year college. Journal of College Science Teaching, 43(4), 12-17.

Jones, M. T., Barlow, A. E., \& Villarejo, M. (2010). The importance of undergraduate research to persistence in biology. Journal of Higher Education 81, 82-115.

Junge, B., Quiñones, C., Kakietek, J., Teodorescu, D., \& Marsteller, P. (2010) Promoting undergraduate interest, preparedness, and professional pursuit in the sciences: An outcomes evaluation of the SURE program at Emory University. CBE-Life Sciences Education, 9(2), 119-132.

Kinkel, D. H., \& Henke, S. E. (2006). Impact of undergraduate research on academic performance, educational planning, and career development. Journal of Natural Resources \& Life Sciences Education, 35(1), 194-201.

Labov, J. B. (2012). Changing and evolving relationships between two-and four-year colleges and universities: They're not your parents' community colleges anymore. CBE-Life Sciences Education, 11(2), 121-128.

Lloyd, P. M., \& Eckhardt, R. A. (2010). Strategies for improving retention of community college students in the sciences. Science Educator, 19(1), $33-41$.

Lopatto, D. (2007). Undergraduate research experiences support science career decisions and active learning. CBE-Life Sciences Education, 6(4), 297-306.

Nagada, B. A., Gregerman, S. R., Jonides, J., von Hippel, W., \& Lerner, J. S (1998). Undergraduate student-faculty research partnerships affect student retention. Review of Higher Education, 22, 55-72.

National Academy of Engineering and National Research Council. (2012) Community colleges in the evolving STEM education landscape: Summary of a summit. Washington, DC: National Academies Press.

President's Council of Advisors on Science and Technology. (2012). Engage to excel: Producing one million additional college graduates with degrees in science, technology, engineering, and mathematics. Washington, DC: U.S. Government Office of Science and Technology.

Provasnik, S., \& Planty, M. (2008). Community colleges: Special supplement to The Condition of Education 2008 (NCES 2008-033). Washington, DC National Center for Education Statistics.

Rooney, J. J., \& Heuvel, L. N. V. (2004). Root cause analysis for beginners. Quality Progress, 37(7), 45.

Zeidenberg, M., Jenkins, P. D., \& Calcagno, J. C. (2007). Do student success courses actually help community college students succeed? Columbia University Academic Commons. Retrieved May 12, 2018, from https:// hdl.handle.net/10022/AC:P:19305 